\title{
Flowering induction, pollen and seed viability and artificial hybridization of taniers (Xanthosoma spp.)'
}

\author{
Ricardo Goenaga and Paul Hepperly
}

\begin{abstract}
Natural flowering and seed set in tanier (Xanthosoma spp.) is rare and limits improvement of the crop through hybridization. A study was conducted to induce uniform flowering with gibberelic acid (GA) in several species of Xanthosoma and to manually pollinate flowers to obtain true botanical seeds. Pollen and seed viability was also sfudied. Uniform flowering of plants was induced by foliar applications of a $500 \mathrm{mg} / \mathrm{L}$ solution of GA. Successful pollinations produced fruits that ripened in about 45 days and resulted in the production of $12 \mathrm{~F}_{\mathrm{I}}$ hybrid combinations and three selfed pollinations. Germination rates of tanier seeds always exceedd $85 \%$ after a storage of more than 7 months at $8 \pm{ }^{\circ} \mathrm{C}$ and $80 \%$ relative humidify. Viability tests showed that pollen stored at $8 \pm{ }^{\circ} \mathrm{C}$ and $80 \%$ relative humidity could remain viable for about 8 days; however, the storage period was strongly dependent on pathogen interaction with the pollen grain.
\end{abstract}

\section{RESUMEN}

Inducción de la floración, viabilidad del polen y la semilla e hibridación en yautías (Xanthosoma spp.)

Se realizó un estudio para inducir con ácido giberélico la floración en varias especies de yautías y polinizar artificialmente las plantas para obtener semilla sexual. También se estudió la viabilidad del polen y las semillas. Se logró inducir la floración uniformemente entre especies mediante aplicaciones foliares de áscido giberélico a concentraciones de $500 \mathrm{mg} . / \mathrm{h}$. Las polinizaciones produjeron frutas que maduraron en 45 días y se logró producir 12 híbridos $F_{1}$ y tres autofecundaciones. El porcentaje de germinación de las semillas se mantuvo en más de $85 \%$ por 7 meses cuando las semillas se almacenaron a $8 \pm{ }^{\circ} \mathrm{C}$ a una humedad relativa de $80 \%$. No obstante, la viabilidad del polen dependió grandemente de la presencia de patógenos en los granos de polen.

\section{INTRODUCTION}

In the past, taniers (Xanthosoma spp.) have been considered a subsistence crop with low research priorities. However, it is regarded as a staple food by about 400 million people in the tropics (2). Because of lack

${ }^{1}$ Manuscript submitted to Editorial Board 18 October 1989.

${ }^{2}$ Research Plant Physiologist, USDA, ARS, Tropical Agriculturel Research Station, Mayagüez, P.R. 00709-70.

${ }^{3}$ Research Plant Pathologist, USDA, ARS, Tropical Agriculture Research Station, Mayaguëz, P.R. 00709-0070. 
of basic research, it has been classified by the National Academy of Sciences (5) as a neglected food crop with promising economic potential.

During the 1950s tanier production in Puerto Rico reached peak production averaging 25,000 metric tons per year. By the 1980 s, production had declined to the lowest level, 5,700 metric tons, and importation of 11,200 metric tons was necessary to satisfy the local demand (1). Unless higher economic yields are obtained the decline in production and the increase in importation will result in higher prices to the consumer. According to Vicente-Chandler (7), about 23,000 metric tons of taniers will be needed to supply the local demand in the year 2000 .

Among the factors responsible for the low yields and the production reduction in Puerto Rico, the dry-root-rot syndrome or "mal seco" (4) and probably viral diseases (5) are the most important.

Tanier has been improved by clonal selection and introduction of superior genotypes. Improvement through hybridization has been hindered by the infrequent appearance of inflorescences. In those few cultivars that do produce flowers, a condition of protogyny exists in which the stigma is receptive before pollen shedding.

Breeding tanier may well ameliorate the root-rot syndrome or produce high yielding cultivars of superior quality and a wide range of adaptability to environmental stress. Variability within the genus Xanthosoma is fairly broad for maturity, cormel texture, taste, color, size, shape, nutritive value and pest resistance (6). However, to breed taniers, one needs considerable knowledge of flower induction, pollination and seed handling.

This study reports on uniform flower induction, viable seed production and pollen and seed viability under ambient and controlled conditions in several species of taniers.

\section{MATERIALS AND METHODS}

The experiment was conducted at the Tropical Agriculture Research Station, Mayagüez, Puerto Rico. The parental plants were established in a screenhouse from excised corm buds that were planted in seedling flats containing Pro-Mix ${ }^{4}$ growing medium. The seven tanier cultivars used for the experiment were Palma, Blanca Dominicana and Rascana ( $X$. spp.), Amarilla del País (X. atrovirens), Blanca del País ( $X$. caracu), and Kelly and Vinola $(X$. violaceum). On 22 March 1988, plants of cultivars at the 2- to 3-leaf stage were transplanted outdoors in $8 \times 0.9 \times 0.7 \mathrm{~m}$ cement boxes under $30 \%$ Saran shade. The experimental design was a split-plot arrangement with four cement boxes serving as replications.

\footnotetext{
Thade names in this publication are used only to provide specific information. Mention of a trade name does not constitute a warranty of materials by the USDA/ARS, nor is this mention a statement of preference over other materials.
} 
The boxes were divided in half (main plots) to accommodate plants receiving gibberelic acid (GA) and those serving as control; cultivars were used as subplots. There were two plants per cultivar spaced $51 \times 51 \mathrm{~cm}$ apart. The experimental plots received $690 \mathrm{~kg} / \mathrm{ha}$ of a 10-5-15 commercial fertilizer at one and five months after planting.

A solution of Pro-Gibb ${ }^{1}$ containing $500 \mathrm{mg} / \mathrm{l}$ of $\mathrm{GA}$ was applied as a foliar spray, in four biweekly applications, beginning 3 June 1988. A spreading agent, $\mathrm{X}-77$, was used at $0.065 \% \mathrm{v} / \mathrm{v}$ and the plants were sprayed to run-off. Control plants were sprayed with a $0.065 \%$ solution of X-77 without the addition of GA.

Ovary receptivity for pollination was determined by the presence of a sticky exudation over female flowers shortly after the spathe unfurled. At this time the spathe and the staminate portion of the flower were excised with a razor blade, and pollen from a flower that had opened 24 hours previously was applied to the entire surface of the stigmas with a camel-hair brush. The pollinated flowers were then covered with pollination bags for about 1 week.

Fruits obtained from crosses were harvested when their color changed from green to pale yellow (fig. 1) at about 45 days after pollination. Each fruit contained several hundred sacs which encased about 20-50 seeds. The sacs were finger-pressed against paper towels for seed removal. Seeds were then allowed to dry in an air-conditioned room, treated with Arasan fungicide, and stored in a refrigerator at $8^{\circ} \mathrm{C}$ and $80 \%$ relative humidity.

Seed germination was tested every 21 days (fig. 2) by random selection of three of the hybrids obtained during the experiment. At each date, three replicates of 25 seeds each were placed in petri dishes on moist Whatman No. 1 filter paper for each hybrid and placed in a growth chamber in a randomized complete block design. Day/night temperatures were controlled to $32.5 / 24.6^{\circ} \mathrm{C}$ with thermoperiods of $12 / 12 \mathrm{~h}$. Illumination was provided by three $20 \mathrm{~W}$ fluorescent lamps located $30 \mathrm{~cm}$ above the petri dishes.

Pollen collected from newly opened flowers was tested for viability with the tetrazolium staining test (3). Collected pollen was divided into two portions and placed in each of two glass jars containing anhydrous calcium chloride. One jar was stored in a refrigerator at $8^{\circ} \mathrm{C}$ and $80 \%$ relative humidity and the other in an air conditioned room with a temperature of about $24^{\circ} \mathrm{C}$ and $56 \%$ relative humidity. To test viability, we placed $3.5 \mathrm{mg}$ of pollen grains on a $25 \times 75 \mathrm{~mm}$ glass slide, added two drops of $1 \% 2,3,5$-triphenyltetrazolium chloride and covered the grains with an 18-mm cover glass. To avoid evaporation of the tetrazolium solution, we placed the slides in petri dishes on moist filter paper and kept them in darkness for $24 \mathrm{~h}$. Viable pollen respires and changes colorless tetrazolium reddish by chemical reduction. This procedure does not 


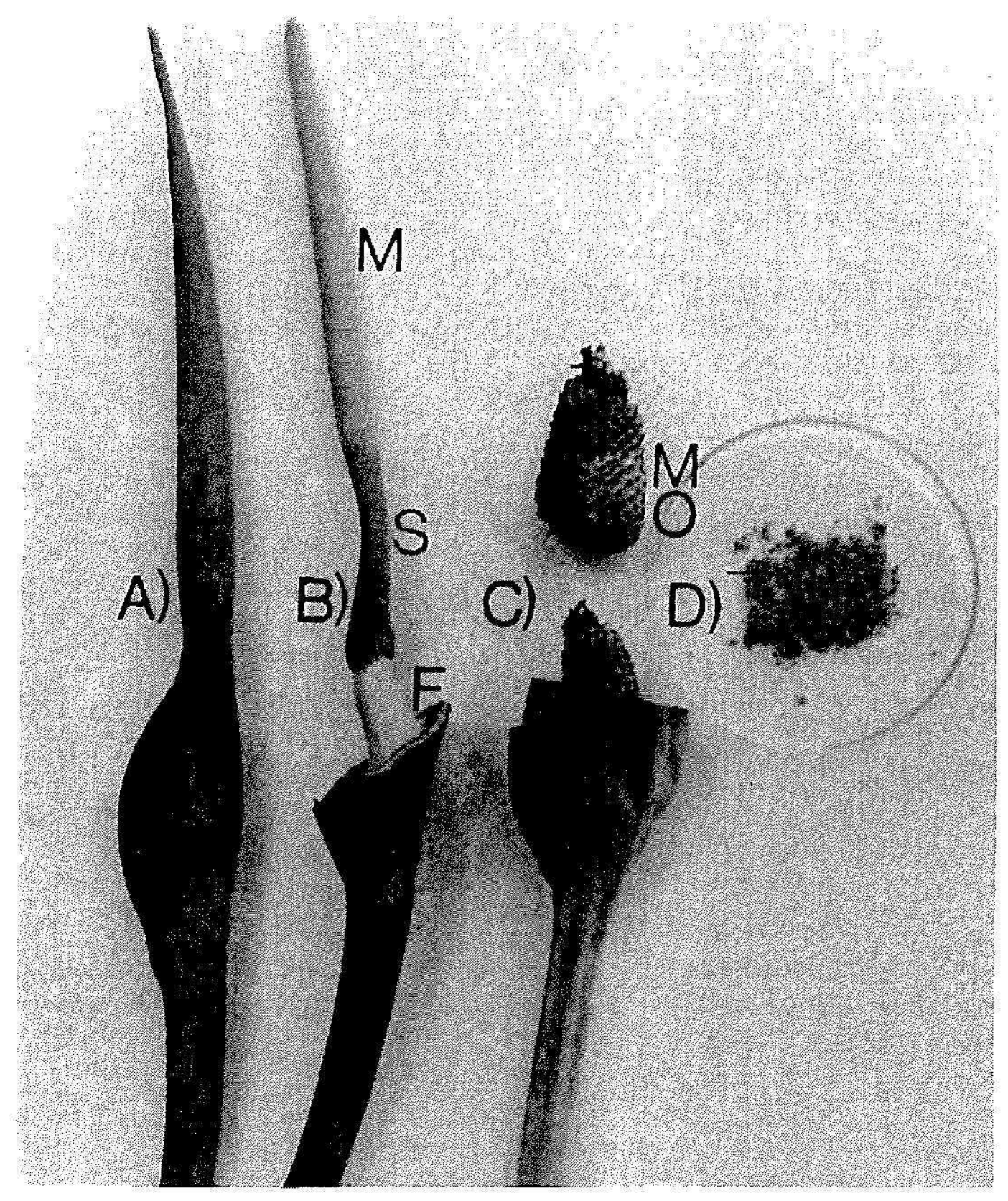

FIG. I.-Reproductive anatomy of taniers (Xanthosoma spp.). A. Flower stalk and spathe (sheathing bract enclosing the spadix). B. Flower stalk with spathe excised to expose the spadix. Male staminate flowers (M), sterile flowers (S), and pistillate flowers (F). C. Senescing flower stalk with partly excised spathe surrounding a mature fruit. Yellow maturing ovaries (MO) developing from basal region to tip. D. Mature seed separated from manually pollinated mature ovaries.

evaluate actual pollen germination or pollen tube growth. Hence, it should be considered as a measure of apparent pollen viability. Nevertheless, nonviable pollen does not respire and hence, does not show dye reduction. 


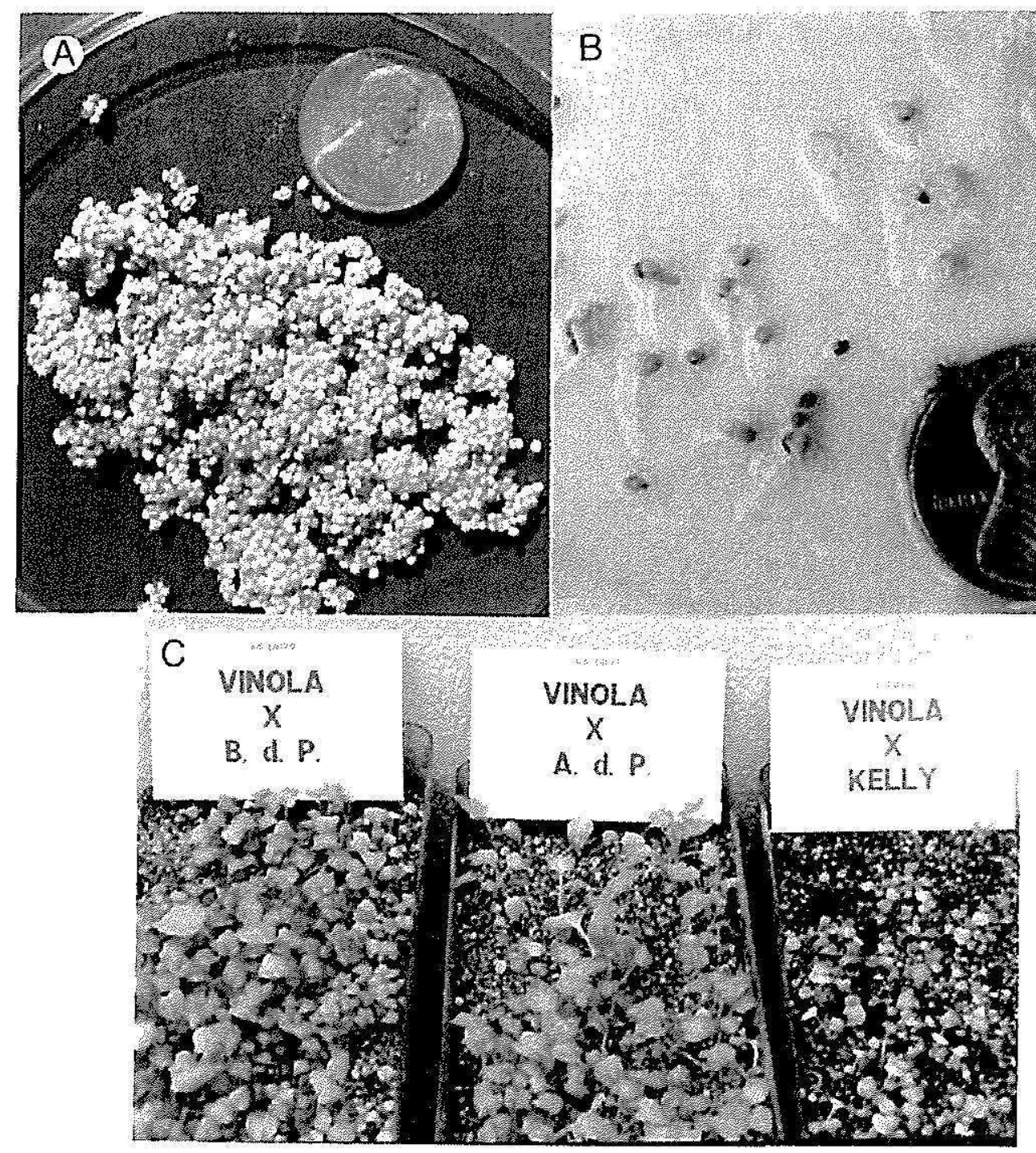

FIG. 2.-Seed and seedling development of taniers (Xanthosoma spp.). A. Mature clean seed magnified approximately 1.5X. B. Seedlings on moist filter paper after incubation for 21 days in a growth chamber at $32.5 / 24.6^{\circ} \mathrm{C}$ day and night temperature, respectively. $\mathrm{C}$. Seedling growth of hybrids 60 and 75 days after planting. Note superior growth of Vinola $\times$ B.d.P. as compared with other combinations.

\section{RESULTS AND DISCUSSION}

Enhanced leaf petiole elongation was observed within 7 days of GA application and was the first evidence of GA activity. GA induced flowering within 90 days of the first application in all cultivars except Palma, which flowered at 90 days or later. Each of the treated plants produced at least one inflorescence; the average production was three inflorescences per plant.

When manual pollinations were not successful, the inflorescence and flower stalk shrivelled and senesced rapidly. Nevertheless, additional production of new flower buds continued for about 3 more months in the 
treated plants. Successful pollinations produced fruits that ripened in about 45 days (fig. 1). Among nontreated plants, only Vinola and Kelly produced a limited number of inflorescences and these occurred late during their growth cycle.

Viable seeds were obtained from the following $F_{1}$ hybrid combinations and self pollinations:

\section{$F_{1}$ hybrid combinations}

Blanca del País $\times$ Blanca Dominicana

Blanca Dominicana $\times$ Amarilla del País

Kelly $\times$ Amarilla del País

Kelly $\times$ Blanca del País

Kelly $\times$ Vinola

Rascana $\times$ Amarilla del País

Rascana $\times$ Blanca del País

Rascana $\times$ Blanca Dominicana

Rascana $\times$ Vinola

Vinola $\times$ Amarilla del País

Vinola $\times$ Blanca del País

Vinola $\times$ Kelly
Self pollinations

Kelly

Vinola

Blanca Dominicana

However, in some instances seed production was affected by the presence of a fruit rot which resulted in fruit abortion. This disease was most prevalent under high rainfall, and attempts to control it with sprayings of a fungicide mixture of metalaxyl, captan, and benomyl were unsuccessful. Pollinations using the Palma cultivar either as a female or male parent failed. Chromosome studies indicate that Palma is a tetraploid $(4 n=52)$, whereas the other cultivars are classified as diploids $(2 \mathrm{n}=26)$ (K. F. Schertz, personal communication).

Seeds obtained (fig. 2) were small (1.0-1.5 mm), and depending on the hybrid combination, varied from yellow to dark brown. The majority of the seeds obtained from these pollinations germinated in the screenhouse in trays containing a 4:1 mixture of Pro-Mix and sand (fig. 2). Germination occurred in 10-12 days. When the seedlings were about $8 \mathrm{~cm}$ high, they were transplanted to jiffy pots. Once seedling roots penetrated the jiffy pots, they were planted in the field where they are currently being evaluated.

Tanier seeds were long-lived when stored at $8^{\circ} \mathrm{C}$. Even after storing seeds for more than 7 months, the germination rates for three of the hybrid combinations always exceeded $85 \%$. Because of the complexity, time involved, and the uncertainty of successful pollinations, these findings are an important step in any breeding effort toward tanier improvement.

Tests on apparent pollen viability showed that at $8^{\circ} \mathrm{C}$, pollen could remain viable for a maximum of 8 days. However, microscopic examina- 


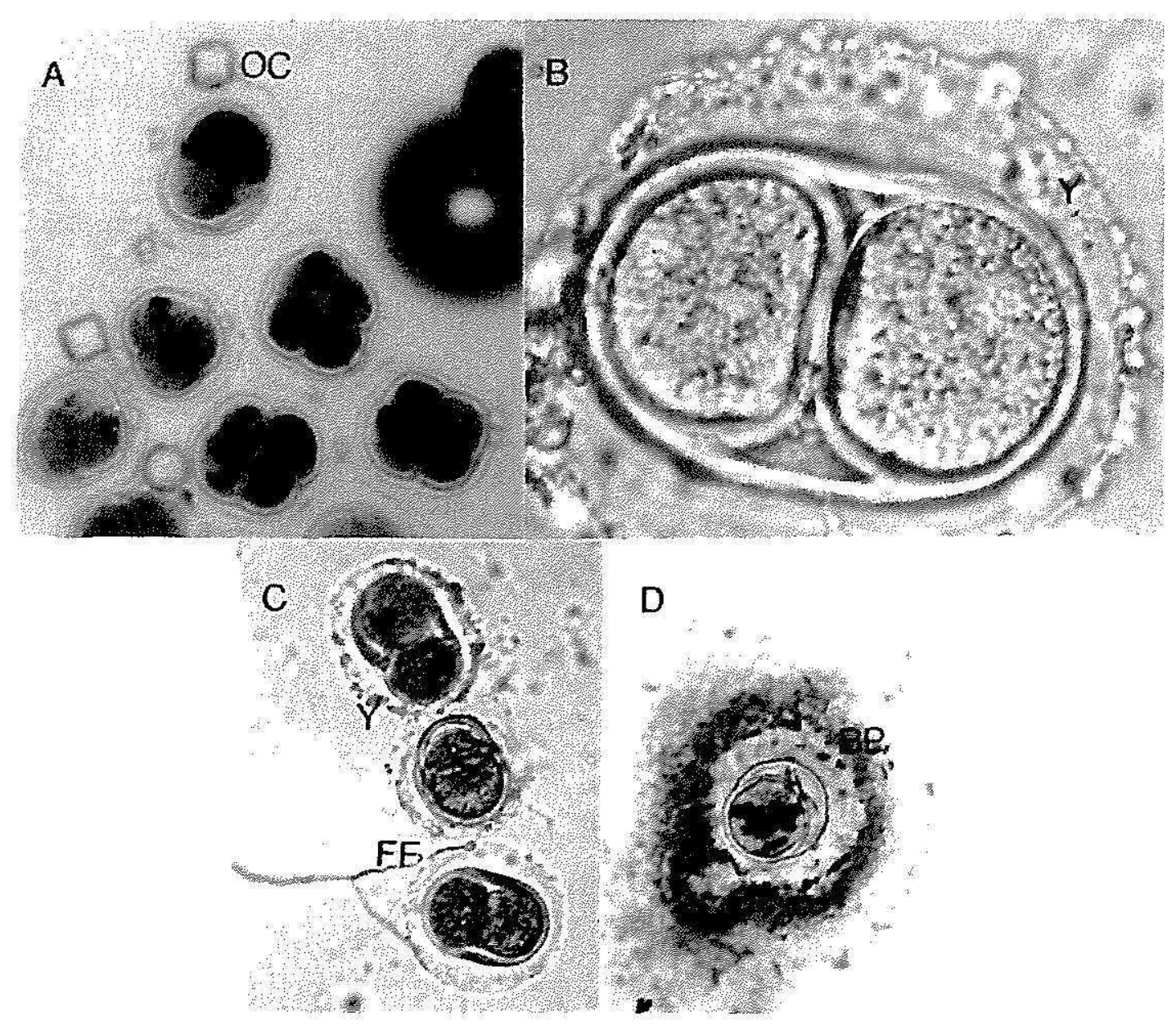

FIG. 3.-Apparent viability of tanier pollen according to tetrazolium red staining. A. Heavily stained pollen tetrads showing high respiratory activity and apparent viability. Note the deep stain of chromosomal material and general pollen grain morphology. Tanier pollen shows a thick outer gelatinous sheath (sticky halo) and a bilayered (exine and intine) wall. In pollen preparations oxalate crystals $(O C)$ were commonly observed. B. Note a nonstaining pollen grain with yeast-like organisms $(Y)$ which proliferate on and within the gelatinous sheath. C. Pollen tetrads showing low respiratory activity (slight staining) and presence of colonization of yeast $(Y)$ and filamentous fungi (FF). D. A halo of bacterial plaque (BP) forming around a single pollen tetrad. Bacteria stained either red or blue with tetrazolium treatment.

tion of hundreds of tetrazolium-treated samples showed that the viability of pollen was substantially reduced when fungi and bacteria developed around and within the pollen grains (fig. 3). For maximum pollen viability immediate use of pollen is recommended. Short term storage under refrigeration is feasible for pollination. Pollen viability drops rapidly (within 72 hours) at temperatures exceeding $24^{\circ} \mathrm{C}$.

\section{LITERATURE CITED}

1. Anonymous, 1986. Oficina de Estadísticas Agrícolas y Oficina de Inspección de Mercados, Departamento de Agricultura, Santurce, Puerto Rico. 
2. Cobley, L. S. and W. M. Steele, 1976. An introduction to botany of tropical crops, 2nd ed, pp. 123-28. English Language Book Society, Longmans, London, England.

3. Delouche, J. C., T. W. Still, M. Raspet and M. Lienhard, 1962. The tetrazolium test for seed viability. Miss. State Agric. Exp. Stn. Tech. Bul. 51.

4. González-Villafañe, E. and B. R. Espinet-Colón, 1977. Análisis económico de la producción de yautías, Puerto Rico, 1975. Bol. 249, Esta. Exp. Agric. Univ. P. R.

5. National Academy of Sciences, 1975. Underexploited tropical plants with promising economic value, pp. 33-7. Washington, D.C.

6. O'Hair, S. K., 1984. Farinaceous Crops, pp. 139-91. In F. W. Martin (Ed). Handbook of Tropical Food Crops. CRC Press, Inc., Boca Raton, Florida.

7. Vicente-Chandler, J., 1985. Una nueva agricultura para Puerto Rico-año 2000. Río Piedras, Puerto Rico. 